\title{
ADULT-ONSET CYSTIC HYGROMA IN AXILLA: A RARE CASE REPORT FROM INDIA AND LITERATURE REVIEW (case report)
}

\author{
*R. Pandey ${ }^{1}$, R. Kumar', S. Maheshwari ${ }^{1}$, \\ T.S. Singh' ${ }^{1}$, S. Bhalla', I.D. Khan ${ }^{2}$ \\ 1 - BASE HOSPITAL, TEZPUR, ASSAM, INDIA \\ 2 - COMMAND HOSPITAL, UDHAMPUR, INDIA
}

Background. Cystic hygroma (CH), occurs in 1/6000 live births and in $90 \%$ of cases develops in age less than 2 years old. They are mainly located in cervicofacial region. Adult-onset $\mathrm{CH}$ is very rare.

Objective. The aim of this study is to review literature to discuss the clinical presentation, diagnosis, and treatment of $\mathrm{CH}$ in adults through a case report of unilocular $\mathrm{CH}$ in the axillary region in an adult male from India.

Methods. A first case report of unilocular $\mathrm{CH}$ in axillary region in an adult male from India is being investigated.

Results. Here we report a case of unilocular $\mathrm{CH}$ in the axillary region in a 49-year-old male with a $14 \times 16 \times 8$ $\mathrm{cm}$ cystic swelling in left axilla with a history of aspiration failure. Contrast-enhanced MRI (CEMRI) showed welldefined thin walled, unilocular cystic lesion which appeared hyperintense on T2 \& STIR and hypointense on T1W1 and showed thin peripheral rim of enhancement on post contrast images. The patient underwent surgical excision and the diagnosis of a pathological $\mathrm{CH}$ was established. His postoperative recovery was uneventful and had no evidence of recurrence.

Conclusion. Due to rarity of adult-onset unilocular $\mathrm{CH}$ in axilla, its evaluation for prompt diagnosis and definitive treatment to prevent recurrence and complications is urgent. Furthermore, this is the first reported case from India which has been successfully managed at a peripheral hospital in Northeast-India and our report of this case contributes to the evidences supporting the role of $\mathrm{CH}$ in a differential diagnosis for masses in the adult axilla, especially in acute phase with no predisposing factors.

KEYWORDS: cystic hygroma; cystic lymphangioma; adult-onset; axilla.

\section{Introduction}

Cystic hygroma $(\mathrm{CH})$, also known as cystic lymphangioma, first described by Redenbacker in 1828 , is a congenital malformation of the lymphatic system, occurring either due to sequestration or obstruction of developing lymph vessels [1-3]. The incidence of $\mathrm{CH}$ is $1 / 6000$ live births [4]. $90 \%$ of $\mathrm{CH}$ develops in the age of less than 2 years and accounts for onetenth of all paediatric soft tissue tumours [2]. The five main locations are cervicofacial, axillary, inguinal, retroperitoneal, and thoracic regions; orbit, shoulder, breast, mediastinum, pancreas, liver, ovary and fallopian tubes are other uncommon sites [1,3].

Adult-onset $\mathrm{CH}$ is very rare; only less than 150 cases have been reported [4]. Its occurrence in axilla is extremely rare [4-7]. At the Indian subcontinent, only three case reports are available in the literature [8-11]. To the best of

*Corresponding author: Rahul Pandey, Assistant Professor Surgery, Department of Surgery, Base Hospital, Tezpur, Assam, 784001, India. E-mail: rahuladviksimpy@gmail.com our knowledge, this is the first reported case of unilocular $\mathrm{CH}$ in the axillary region in an adult male from India. In view of extremely rarity of the disease in adults we review the literature to discuss clinical presentation, diagnosis, and treatment of $\mathrm{CH}$.

\section{Case Report}

A 49-year-old male, with no known comorbidities, noticed a spontaneous onset of palpable mass in the left axillary area in Jan 2021 and had initially reported to a medical centre. The lesion was soft, movable, non-tender with smooth skin surface at onset. Initial ultrasonography (USG) of left axilla revealed a $64 \times 42 \times 46 \mathrm{~mm}$ unilocular cystic lesion with no calcifications within. Fine needle aspiration cytology (FNAC) proved a benign cystic lesion with no evidence of malignancy. The patient underwent USG guided percutaneous aspiration on Jan 16, 2021 and straw-coloured fluid was aspirated. However, the mass recurred in one week after aspiration. It kept growing slowly 
and became tense in four months. On examination at our centre, there was a $14 \times 16 \times 8 \mathrm{~cm}$ cystic swelling in left axilla, extending to lateral chest wall, not attached to underlying muscles or overlying skin as shown in Fig. 1. The swelling was non-compressible and non-pulsatile. There were no other palpable axillary masses grossly. The patient denied any history of trauma at the affected area, any recent infections and there was no loss of weight or appetite.

USG axilla at our centre found an $8 \times 10.5 \times 11 \mathrm{~cm}$ unilocular cystic lesion in left axilla. No calcification/internal vascularity or breach in deep fascia was noted. The contrastenhanced MRI (CEMRI) of left axillary region showed well-defined thin walled, unilocular cystic lesion, $10.5 \times 9.5 \times 11.5 \mathrm{~cm}$ in size extending inferiorly along the lateral chest wall. It was hyperintense on T2 \& STIR and hypointense on T1W1 as shown in Fig. 2. The lesion showed thin peripheral rim of enhancement on post contrast images. Neither invasion of underlying muscles or lateral chest wall nor locoregional lymphadenopathy was seen.

In view of failure of image-guided percutaneous aspiration at the previous centre, decision of surgical excision was taken. Tumour

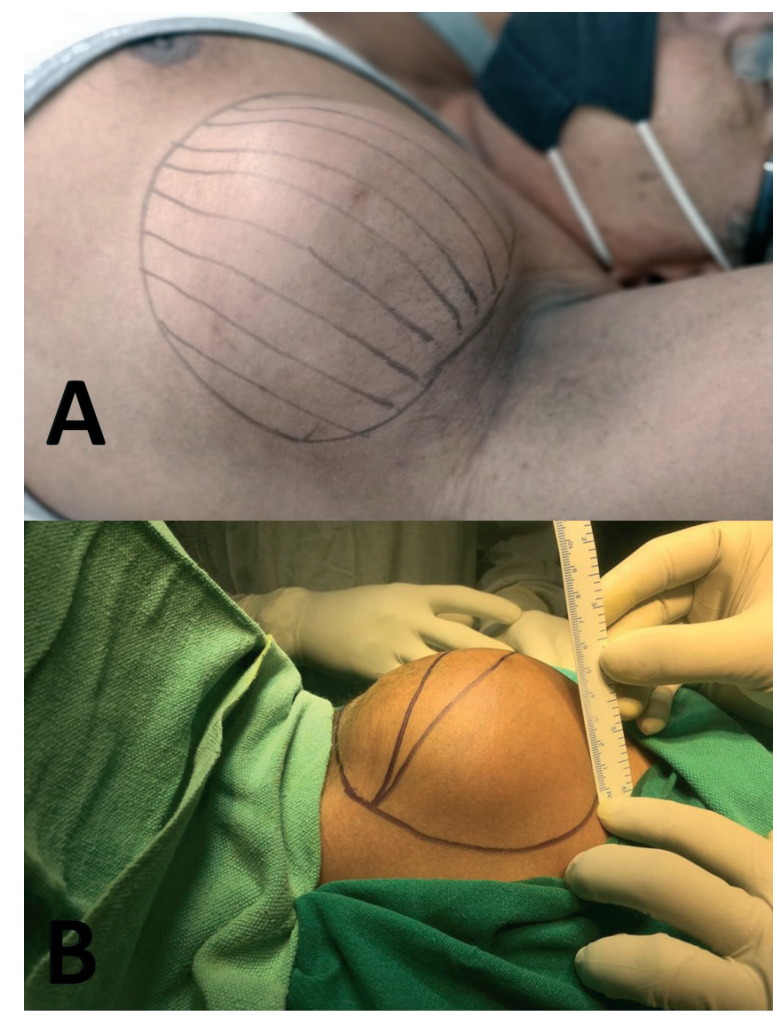

Fig. $1(A, B)$. Preoperative image showing $14 \times 16 \times 8 \mathrm{~cm}$ cystic swelling in left axilla, extending to lateral chest wall, not attached to underlying muscles or overlying skin.
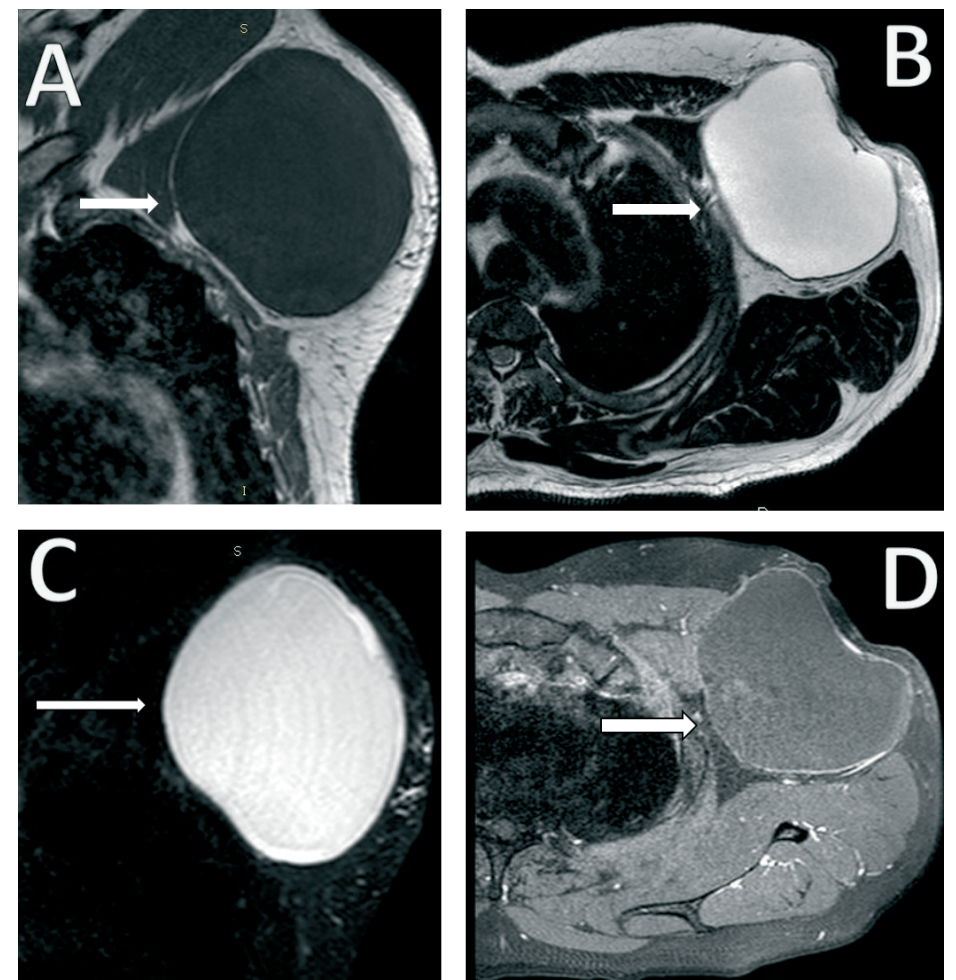

Fig. 2. (A) T1WI sagittal section showing a large, well-defined, thin walled, unilocular cystic lesion, size $10.5 \times 9.5 \times 11.5 \mathrm{~cm}$ $(A P \times T R \times C C)$ was evidenced in the left axillary region extending inferiorly along the lateral chest wall. The lesion was hypointense on T1WI. (B) T2WI axial section, showing hyperintense lesion with no internal septae/calcifications/mural nodules. (C) STIR coronal section image showing lesion as hyperintense. (D) Post contrast axial image of lesion with thin peripheral rim of enhancement. 
excision was performed under general anaesthesia. Intraoperative findings were $15 \times 15 \mathrm{~cm}$ cystic swelling in left axilla extending from pectoralis major to latissimus dorsi anteroposteriorly and from axillary vein to angular vein craniocaudally. The intraoperative image and excised specimen are shown in Fig. 3 and 4 respectively. Fluid filled cyst with intact cyst wall was completely excised. The wound was primarily closed over suction drain. The drain was removed on postoperative day five. The patient was discharged after suture removal on postoperative day eight and was under regular follow-up via video-consultation due to the imminent threat of COVID-19 pandemic.

The tumour grossly appeared brownish and elastic, and the pathological diagnosis was $\mathrm{CH}$. Under microscopy, the specimen was composed of thin-walled lymphatic spaces lined by flat epithelium with a collagenous background and accompanying lymphocytic infiltrates in the surrounding fibroadiposal stroma as shown in Fig. 5.

\section{Discussion}

$\mathrm{CH}$ is a benign and painless malformation of lymphatic system either due to sequestration or proliferation of lymphatics. It comprises $6 \%$ of all paediatric soft tissue tumours and usually presents in infants prior to the age of 1 year, and about $90 \%$ of the lesions occur in children younger than 2 years [12]. The most common sites of occurrence are the posterior triangle of the neck (75\%), axilla (20\%), and mediastinum. However, it may also involve groin, retroperitoneal space and pelvis [3].

$\mathrm{CH}$ is rare in adult and very few cases have been reported in literature $[4,5,7,10-21]$. Development of $\mathrm{CH}$ in adulthood is caused by delayed proliferation of cell rests with infection,

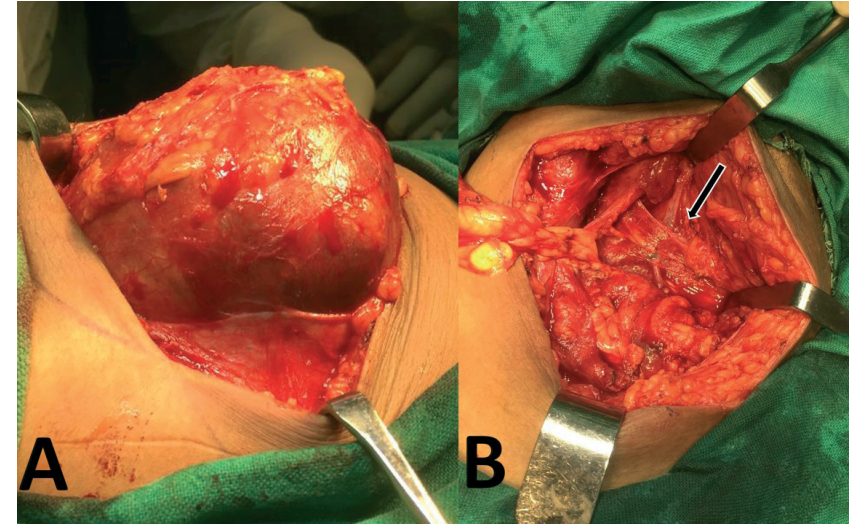

Fig. 3. (A) - Intraoperative image showing well encapsulated unilocular macrocystic lesion. (B) - Intraoperative image, surgical bed with completely excised lesion and arrow pointing at the neurovascular pedicle lying in close proximity.

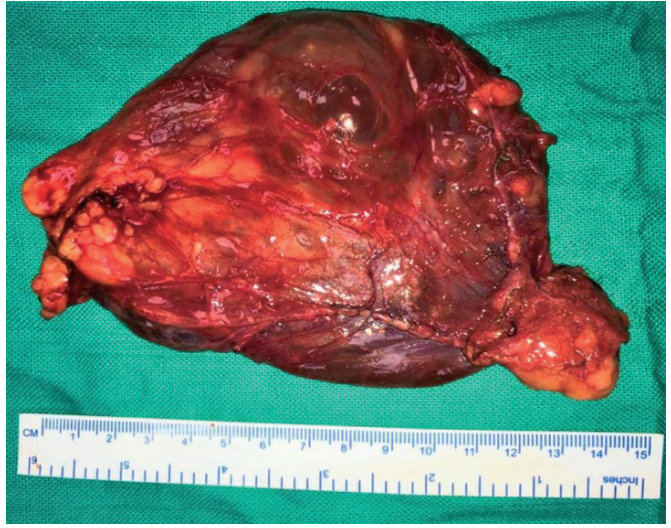

Fig. 4. Gross image of the excised specimen showing a transparent well circumscribed unilocular macrocystic lesion with straw-coloured fluid within it.

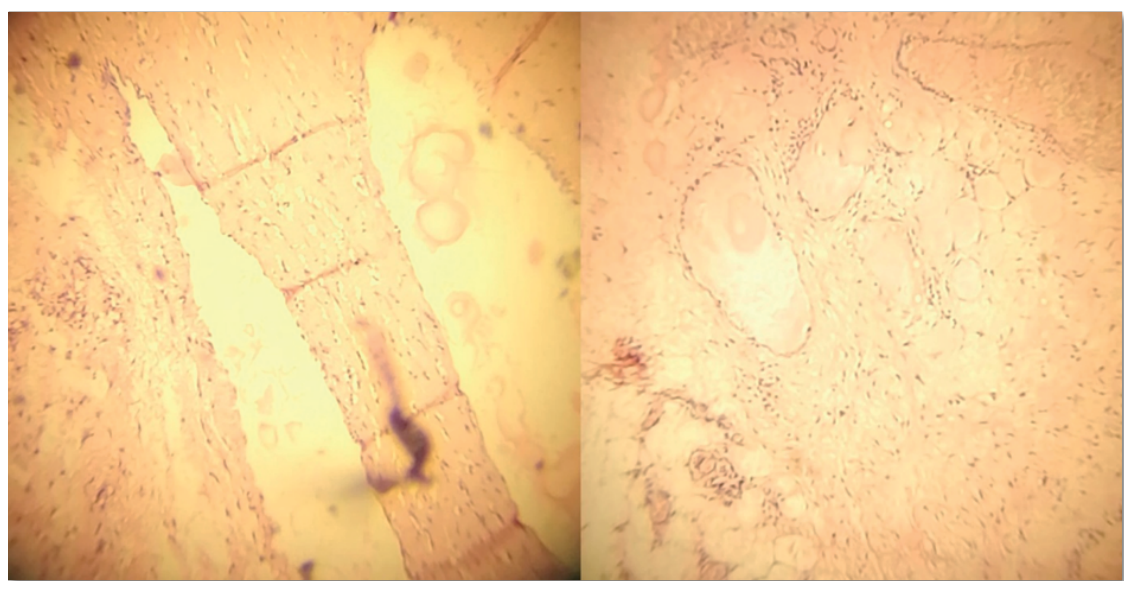

Fig. 5. Microscopic image, 40× magnification, in hematoxylin and eosin (H\&E) stain, showing components of thin-walled varying sized dilated lymphatic spaces lined by flattened epithelium with chronic inflammatory cells in fibrous stroma, compatible with cystic hygroma. 
trauma, or iatrogenic stimuli as being the predisposing factors. Michail et al. reported a cystic hygroma in a female patient which developed rapidly in the axillary region in the absence of any predisposing factors [7].

Axillary $\mathrm{CH}$ in adults is usually asymptomatic. On physical examination, it appears as painless, mobile cystic swelling with well-defined margins, is fluctuant and compressible. The clinical course is usually progressive. Rapid progression is due to lymph accumulation or on-going haemorrhage inside that may lead to rupture of the cyst. Pain and erythema over the swelling indicates cellulitis or lymphangitis which may progress to sepsis. Most common organisms responsible for infection in $\mathrm{CH}$ are staphylococcus and streptococcus.

Differential diagnosis of $\mathrm{CH}$ includes lymphadenopathy, abscess, hematoma and soft tissue sarcoma. Diagnosis can be made with adequate history and its characteristic appearance on clinical examination. USG, computed tomography and MRI are all helpful imaging tools to confirm the diagnosis $[5,6]$. MRI is superior to computed tomography as it offers detailed information about the soft tissue mass and it also provides appropriate preoperative staging and exact anatomical delineation for surgical planning. In the described case, lesion appeared hyperintense on T2 \& STIR and hypointense on T1W1 as shown in Fig. 2. The lesion showed thin peripheral rim of enhancement on post contrast images. Role of Fine needle aspiration cytology (FNAC) in diagnostic workup of $\mathrm{CH}$ is criticised due to risk of infection and bleeding associated with the procedure. Walter Colangeli et al reported in their study that FNAC had a low diagnostic value and it did not modify the treatment approach $[14,22]$. In the described case, FNAC was performed as initial workup before the patient reported at our centre and hence it was not repeated due to its limited yield in diagnosis. Grossly CH may appear as unilocular or multilocular cystic lesions with varying size and is classified as microcystic (size of the cyst less than two cm), macrocystic (size of the cyst more than two cm) and mixed variety [14]. Microscopically $\mathrm{CH}$ on $\mathrm{H} \& \mathrm{E}$ staining appears as varying sized dilated lymphatic channels with chronic inflammatory cells in fibrous stroma [3, $4,23]$. In our case, unilocular macrocystic $\mathrm{CH}$ was present in axilla and diagnosis was confirmed on final histopathology.

Indications of treatment for $\mathrm{CH}$ are cosmesis, any associated complications like lymph leakage, repeated inflammation and pressure effect due to cyst. Treatment options for adultonset $\mathrm{CH}$ range from minimally invasive procedures to surgical excision [24]. Minimally invasive modalities include image guided aspiration and intralesional sclerotherapy (using bleomycin, OK-432, doxycycline, acetic acid, alcohol, hypertonic saline) and serial laser therapy [25-26]. Sandeep K Rahul et al have advocated successful use of bleomycin sclerotherapy for a series of $\mathrm{CH}$ at unusual sites [27]. Although aspiration followed by sclerotherapy is the preferred modality in infants, however few studies have also shown its inefficacy [15, $28,29]$. Copley at al reported a case of $\mathrm{CH}$ in the axilla, which was managed by ultrasound guided aspiration but it was unsuccessful due to recurrence, which was then managed successfully by total excision [30]. Failure and complications of sclerotherapy due to immune response to OK-432 in multiloculated, microcystic and mixed variety of $\mathrm{CH}$ have also been frequently reported [31].

Minimally invasive procedures might have been the standard of care for infantile $\mathrm{CH}$ but surgical excision is still the mainstay of treatment for adult onset $\mathrm{CH}$ as the lesion is well circumscribed [16, 21, 23]. Few centres have advocated a combined method of conservative excision with deroofing of a cyst plus intralesional sclerotherapy, in cases where complete excision is not possible and damage to vital structures are predicted [16]. Risk of rupture of cyst per operatively, inadequate partial excision due to its proximity to vital structures and recurrence are the drawbacks with surgical therapy [32]. In the described case, decision for surgical excision was taken in view of failure of image-guided aspiration, well encapsulated unilocular macrocystic uncomplicated adultonset $\mathrm{CH}$ in axilla with minimal neurovascular sacrifice.

Long-term follow up is suggested as very few cases of adult onset $\mathrm{CH}$ is available in literature [17]. Güner et al [5] managed a case of axillary cystic hygroma in an 83-year-old male and did not find any recurrence during five months' follow-up period. McCaffrey et al. [4] reported a case of cystic hygroma in a 58-yearold male in right upper flank extending up to axilla and there was no recurrence on follow-up in one year after surgery. The patient in our described case is regularly being followed up via video-consultation and has had no recurrence or complications till now. 


\section{Conclusion}

Due to rarity of adult-onset unilocular $\mathrm{CH}$ occurring in axilla, its evaluation for prompt diagnosis and definitive treatment to prevent recurrence and complications is a topical issue. Furthermore, this becomes the first reported case from India which has been successfully managed at a peripheral hospital in NortheastIndia and our reporting of this case contributes to the evidences supporting the role of $\mathrm{CH}$ in a differential diagnosis for masses in the adult axilla, especially in acute stage with no predisposing factors. $\mathrm{CH}$ presents as a soft, painless, and movable cystic mass. Contrast enhanced MRI is the imaging modality of choice as it helps in confirming the diagnosis as well as preoperative planning. Although a gamut of treatment options is available for treating this benign condition, surgical excision is still the procedure of choice for adult-onset $\mathrm{CH}$. Furthermore, management of adult-onset $\mathrm{CH}$ in the axilla with proximity to important neurovascular structures is contributed by our description of this rare case.

\section{Conflict of Interests}

Authors declare no conflict of interest.

Authors' Contributions

Rahul Pandey, Ranjan Kumar - conceptualization, methodology, formal analysis, writing original draft, writing - reviewing and editing; Sandip Maheshwari, Thongam Sachin Singh data curation, writing - reviewing and editing; Sandeep Bhalla, Inam Danish Khan-investigation, formal analysis.

\title{
КІСТОЗНА ГІГРОМА ПАХВИ У ДОРОСЛИХ: РІДКІСНИЙ ВИПАДОК 3 ІНДІЇ ТА ОГЛЯД ЛІТЕРАТУРИ (кЛінічний випадок)
}

\author{
*R. Pandey', R. Kumar'1, S. Maheshwari', \\ T.S. Singh', S. Bhalla', I.D. Khan ${ }^{2}$ \\ 1 - BASE HOSPITAL, TEZPUR, ASSAM, INDIA \\ 2 - COMMAND HOSPITAL, UDHAMPUR, INDIA
}

Вступ. Кістозна гігрома (КГ) зустрічається у 1/6000 новонароджених і в 90\% випадків розвивається у віці до 2 років. Зазвичай КГ локалізується в шийно-лицевій діянці. КГ у дорослих зустрічається надзвичайно рідко.

Мета. Завданням цього дослідження є огляд літератури та обговорення клінічної картини, діагностики та лікування КГ у дорослих з описом випадку однокамерної КГ пахви у дорослого чоловіка з Індії.

Методи. Повідомляється про перший випадок однокамерної КГ пахви у дорослого чоловіка з Індії.

Результати. Описаний випадок однокамерної КГ в пахвовій ділянці у 49-річного чоловіка з кістозною пухлиною $14 \times 16 \times 8 \mathrm{CM}$ в лівій пахвовій западині з невдалою аспірацією в анамнезі. МРТ з контрастом (CEMRI) продемонструвала чітко виражений тонкостінний однокамерний кістозний утвір, який виявився гіперінтенсивним на T2 ma STIR і гіпоінтенсивним на T1W1 ma мав тонкий підсилений периферичний обідок на постконтрастних зображеннях. Пацієнту проведено хірургічне висічення утвору та встановлено післяопераційний діагноз КГ. Післяопераційний період в пацієнта проходив без ознак рецидиву.

Висновок. Однокамерна КГ пахви є рідкісним явищем, тому їі правильна діагностика та вибір оптимальної тактики лікування для запобігання рецидивам і ускладненням має першочергове значення. Крім того, даний випадок є першим зареєстрованим в Індії, успішне лікування було проведене в умовах периферичної лікарні на північному сході Індії. Даний випадок і повідомлення про нього підтверджують роль КГ у диференціальній діагностиці новоутворів пахви у дорослих, особливо тих, що виникають гостро і без передумов.

КЛючОВІ СЛОВА: кістозна гігрома; кістозна лімфангіома; захворювання дорослих; пахва.

\section{Information about the authors}

Rahul Pandey, Assistant Professor Surgery, Department of Surgery, Base Hospital, Tezpur, Assam, India

ORCID 0000-0003-2624-5113, e-mail: rahuladviksimpy@gmail.com India

Ranjan Kumar, Assistant Professor Surgery, Department of Surgery, Base Hospital, Tezpur, Assam,

ORCID 0000-0002-4573-2446, e-mail: ranjan_afmc@yahoo.co.in 
Sandip Maheshwari, Assistant Professor Radiology, Department of Radiology, Base Hospital, Tezpur, Assam, India

ORCID 0000-0002-0722-7289, e-mail: sandip_7001@yahoo.co.in

Thongam Sachin Singh, Assistant Professor Pathology, Department of Radiology, Base Hospital, Tezpur, Assam, India

ORCID 0000-0002-5029-8066, e-mail: sachinthongam@gmail.com

Sandeep Bhalla, Consultant Community Medicine \& Commandant, Base Hospital, Tezpur, Assam, India ORCID 0000-0001-9027-0001, e-mail: bhallasap@gmail.com

Inam Danish Khan, Associate Professor Clinical Microbiology and Infectious Diseases, Command Hospital, Udhampur, India

ORCID 0000-0002-9824-8711, e-mail: titan_afmc@yahoo.com

\section{References}

1. Akar E. Various anatomic localizations of cystic hygroma: a retrospective analysis of 16 cases. The Turkish Journal of Thoracic and Cardiovascular Surgery 2017;25:242-248.

DOI: $10.5606 /$ tgkdc.dergisi.2017.13439

2. Lodhia J, Philemon R, Amsi P, et al. A Report of a Large Axillary Cystic Hygroma (a.k.a Lymphangioma) in a Newborn from a Tertiary Hospital in Northern Tanzania. Case Rep Surg 2020;2020: 5624019-5624019.

DOI: $10.1155 / 2020 / 5624019$

3. Mirza B, Ijaz L, Saleem M, et al. Cystic hygroma: an overview. J Cutan Aesthet Surg 2010; 3: 139-144.

DOI: $10.4103 / 0974-2077.74488$

4. McCaffrey F, Taddeo J. Surgical management of adult-onset cystic hygroma in the axilla. Int J Surg Case Rep 2014;7:29-31.

DOI: 10.1016/j.ijscr.2014.11.017

5. Güner A, Aydin A, Çelik F. Cystic hygromas in adults: Reports of two cases. Bakırköy Tıp Dergisi 2006;2:101-103.

6. Smith RC, Sherk HH, Kollmer C, et al. Cystic lymphangioma in the adult: An unusual axillary mass. Magnetic Resonance Imaging 1989; 7: 561-563.

DOI: 10.1016/0730-725X(89)90411-6

7. Michail O, Michail P, Kyriaki D, et al. Rapid Development of an Axillary Mass in an Adult: A Case of Cystic Hygroma: Southern Medical Journal 2007; 100:845-849.

DOI: $10.1097 / S M J .0 b 013 e 3180 f 60 e 09$

8. Mansingani S, Desai N, Pancholi A, et al. A case of axillary cystic hygroma. Indian Journal of Radiology and Imaging 2005;15:517.

9. Veeraraghavan G, Denny C, Lingappa A. Cystic hygroma in an adult; a case report. Libyan J Med 2009; 4:160-161.

DOI: $10.4176 / 090608$

10. Bahl S, Shah V, Anchlia S, et al. Adult-onset cystic hygroma: A case report of rare entity. Indian J Dent 2016;7:51-54.

DOI: $10.4103 / 0975-962 X .179374$

11. Shukla S, Shivhare R, Lal V, et al. Cystic lymphangioma of breast and axillary region in an adult: a rare presentation. International Surgery Journal 2020;8:391-394.

DOI: 10.18203/2349-2902.isj20205911
12. Manikoth P, Mangalore G, Megha V. Axillary Cystic Hygroma. Journal of Postgraduate Medicine 2004;50:215-216.

13. Karabulut D, Kula O, Ustabasioglu FE, et al. Imaging findings of axillary cystic lymphangioma in adult. Diagnostic and Interventional Imaging 2018;99: 111-113.

DOI: $10.1016 /$ j.diii.2017.06.007

14. Colangeli W, Facchini V, Kapitonov A, et al. Cystic lymphangioma in adult: a case report and a review of the literature. Journal of Surgical Case Reports; 2020. Epub ahead of print 1 July 2020.

DOI: $10.1093 /$ jscr/rjaa179

15. Loetscher KCQ, Jandali A-R, Garzoli E, et al. Axillary Cavernous Lymphangioma in Pregnancy and Puerperium. GOI 2005;60:108-111.

DOI: $10.1159 / 000085584$

16. Lian HH, Sha PP. Late- Onset Cystic Hygromas Presenting in an Adult: A Case Report. 2016; 3.

17. Schefter RP, Olsen KD, Gaffey TA. Cervical Lymphangioma in the Adult. Otolaryngol Head Neck SURG 1985:93:65-69.

DOI: $10.1177 / 019459988509300113$

18. Chotai N, Fok E, Chan P, et al. Axillary lymphangioma in an asymptomatic adult female. The Breast Journal 2018;24:415-416.

DOI: $10.1111 /$ tbj.12915

19. Elshaar K, AbuAleid L. Adult-onset giant cervical cystic hygroma with pressure manifestations on aerodigestive tract, managed surgically: reporting of a rare case. Ann R Coll Surg Engl 2019;101: e84-e87.

DOI: $10.1308 /$ rcsann.2018.0214

20. Nguyen K, Karsif K, Lee S, et al. Lymphangioma in an Elderly Patient: An Unusual Cause of Axillary Mass. The Breast Journal 2011;17:416-417. DOI: $10.1111 / j .1524-4741.2011 .01103 . x$

21. Naidu SI, McCalla MR. Lymphatic malformations of the head and neck in adults: a case report and review of the literature. Ann Otol Rhinol Laryngol 2004; 113:218-222.

DOI: $10.1177 / 000348940411300309$

22. Suk S, Sheridan M, Saenger JS. Adult lymphangioma: a case report. Ear Nose Throat J 1997;76: 881-883.

PMID: 9431778 
23. Park T, Lee HS, Jung EJ, et al. Concomitant breast and axillary lymphangioma in an adult: A case report and a review of the literature. Medicine; 97, https://journals.Iww.com/md-journal/Fulltext/ 2018/ 11090/Concomitant_breast_and_axillary_lymphangioma_in_an.9.aspx (2018).

24. Adams MT, Saltzman BS, Perkins JA. Treatment of Lymphatic Malformations: A Systematic Review. Otolaryngol Head Neck Surg 2011;145:P249-P249.

DOI: $10.1177 / 0194599811415823 a 374$

25.Adams MT, Saltzman B, Perkins JA. Head and Neck Lymphatic Malformation Treatment: A Systematic Review. Otolaryngol Head Neck Surg 2012;147: 627-639.

DOI: $10.1177 / 0194599812453552$

26. Figaro N, Rampersad R, Juman S. Doxycycline Sclerotherapy of a Cervical Cystic Hygroma: A Caribbean Institution Experience. Case Reports in Otolaryngology 2020;2020:9187205.

DOI: $10.1155 / 2020 / 9187205$

27. Rahul SK, Kumar B, Bhatnagar A, et al. Unusual Site for Cystic Hygroma: A Single Centre Experience. J Cutan Aesthet Surg 2016;9:287-289.

DOI: 10.4103/0974-2077.197091
28. Gow L, Gulati R, Khan A, et al. Mihaimeed F. Adult onset cystic hygroma: a case report and review of management. Grand rounds.

29. Michail O, Michail P, Kyriaki D, et al. Rapid Development of an Axillary Mass in an Adult: A Case of Cystic Hygroma: Southern Medical Journal 2007; 100:845-849.

DOI: $10.1097 / S M J .0 b 013 e 3180 f 60 e 09$

30. Copley PC, Ali L, Mirza S. Spontaneous lymphocoele: an unusual cause of an axillary mass. Case Reports 2016;2016:bcr2015213088.

DOI: $10.1136 /$ bcr-2015-213088

31. Manzini M, Schweiger C, Manica D, et al. Response to OK-432 sclerotherapy in the treatment of cervical lymphangioma with submucosal extension to the airway. Brazilian Journal of Otorhinolaryngology 2020;86:127-129.

DOI: $10.1016 /$ j.bjorl.2016.04.016

32. Sherman BE, Kendall K. A unique case of the rapid onset of a large cystic hygroma in the adult. American Journal of Otolaryngology 2001;22:206-210.

DOI: 10.1053 /ajot.2001.23430

Received 14 May 2021; revised 19 Jun 2021; accepted 20 Jun 2021.

This is open access article distributed under the Creative Commons Attribution License, which permits unrestricted use, distribution, and reproduction in any medium, provided the original work is properly cited. 